Brit. Heart J., 1965, 27, 505.

\title{
CONGENITAL AORTIC STENOSIS PRODUCED BY A UNICOMMISSURAL VALVE
}

\author{
BY \\ WILLIAM C. ROBERTS AND ANDREW G. MORROW \\ From the Clinic of Surgery, National Heart Institute, National Institutes of Health, Bethesda, Maryland, U.S.A.
}

Received September 25, 1964

At the National Heart Institute we have studied a large number of patients in whom obstruction to left ventricular outflow resulted from a congenital malformation of the aortic valve. In each, the congenital basis of the stenotic lesion was established by a history of a præcordial murmur before the age of 5 years and/or by the structure of the valve as determined at open operation or at necropsy. In 4 of these patients, the valve was proved to consist of only a single cusp and a single commissure. This report summarizes the clinical and pathological findings in these 4 patients, and calls attention to the importance of recognizing this unusual form of valvular aortic stenosis when operative treatment is undertaken.

\section{CASE REPORTS}

Case 1. A 28-year-old mechanic grew and developed normally. A præcordial murmur was discovered during a routine examination when he was 17 years of age. He was asymptomatic until 5 months before admission when he developed dyspnœa on exertion, orthopnœa, hæmoptysis, hepatomegaly, and œdema of the ankles. On examination, the blood pressure was $100 / 80 \mathrm{~mm}$. $\mathrm{Hg}$. A grade $2 / 6$ ejection-type systolic murmur and a grade $2 / 6$ blowing diastolic murmur were heard at the base of the heart and along the left sternal border. A third heart sound was audible at the cardiac apex. The electrocardiogram disclosed left bundlebranch block. The chest radiograph showed considerable cardiomegaly with particular prominence of the left ventricle and left atrium. The patient died one month after admission while being treated for severe congestive cardiac failure.

Case 2. A 16-year-old boy had been found to have a præcordial murmur at birth, but his growth and development were normal. At the age of 11 years, he first noted occasional substernal chest pain and, in subsequent years, mild exertional dyspnœa and easy fatiguability developed. On examination, a grade 5/6 ejection-type systolic murmur was heard at the base of the heart and over the carotid arteries. No diastolic murmur was audible. The electrocardiogram showed left ventricular hypertrophy and a left ventricular conduction delay. Radiographic examinations revealed moderate left ventricular enlargement. At left heart catheterization the mean left atrial pressure was $17 \mathrm{~mm}$. $\mathrm{Hg}$, the left ventricular pressure $230 / 8 \mathrm{~mm} . \mathrm{Hg}$. and the brachial arterial pressure, measured simultaneously, 105/75 $\mathrm{mm}$. $\mathrm{Hg}$. The peak systolic pressure gradient was $125 \mathrm{~mm}$. Hg. The evening before a scheduled operation the patient suddenly developed ventricular fibrillation and died.

Case 3. A 9-year-old boy was found to have a præcordial murmur at birth. Growth and development were normal and he was entirely asymptomatic. Examination disclosed a grade $4 / 6$ ejection-type systolic murmur at the base of the heart, which was referred over the entire præcordium and into the neck. No diastolic murmur was audible. The electrocardiogram was interpreted as normal, and chest radiograph disclosed only mild left ventricular enlargement. Cardiac catheterization disclosed normal pressures in the right-sided cardiac chambers. The pressures in the left ventricle (percutaneous puncture) and brachial artery were $190 / 11$ and $104 / 50 \mathrm{~mm}$. $\mathrm{Hg}$, respectively, giving a peak systolic pressure gradient of $86 \mathrm{~mm} . \mathrm{Hg}$. 
On August 8, 1958, aortic valvulotomy was performed during extracorporeal circulation and a period of elective cardiac arrest induced with potassium citrate. The orifice of the aortic valve was eccentric and the valve appeared to be of the usual bicuspid type with fusion of the posterior of the two commissures. Accordingly, the valve was incised posteriorly from the orifice to the aortic wall. When circulation was restored, there was evidence of severe aortic regurgitation; the left ventricle was dilated, and a diastolic thrill was palpable in the aorta and left ventricle. After operation, the patient bled excessively and was returned to the operating room for evacuation of a hæmothorax. Cardiac standstill occurred during this procedure and resuscitation was unsuccessful.

Case 4. A 32-year-old housewife had been found to have a præcordial murmur at the age of 5 years. Growth and development were normal and she was asymptomatic until age 29 when she developed streptococcal endocarditis, which responded to treatment with penicillin. Thereafter, she was well until 5 months before admission when angina pectoris and signs and symptoms of right- and left-sided congestive cardiac failure developed. On examination, a grade $3 / 6$ ejection-type systolic murmur was heard at the base of the heart and over the carotid arteries. No diastolic murmur was audible. The electrocardiogram indicated a previous anterior myocardial infarct, left ventricular and left atrial hypertrophy, and S-T segment changes compatible with subendocardial injury. A percutaneous left ventricular puncture revealed a left ventricular pressure of 176/26 mm. $\mathrm{Hg}$; simultaneous brachial arterial pressure was $82 / 66 \mathrm{~mm}$. $\mathrm{Hg}$; the peak systolic pressure gradient was $90 \mathrm{~mm}$. $\mathrm{Hg}$. The patient's cardiac failure was refractory to treatment, and she died one month after admission.

The relevant clinical data concerning each of the patients are summarized in the Table.

TABLE

Clinical and Pathological features in 4 Patients with Unicommissural Aortic Valvular Stenosis

\begin{tabular}{|c|c|c|c|c|c|c|c|c|c|c|c|}
\hline $\begin{array}{l}\text { Case } \\
\text { No. }\end{array}$ & $\begin{array}{l}\text { Age (yr.) } \\
\text { at death, } \\
\text { and sex }\end{array}$ & $\begin{array}{c}\text { Age (yr.) } \\
\text { præcordial } \\
\text { murmur } \\
\text { first } \\
\text { detected }\end{array}$ & $\begin{array}{c}\text { Age (yr.) } \\
\text { cardiac signs } \\
\text { or symptoms } \\
\text { appeared }\end{array}$ & $\begin{array}{l}\text { Angina } \\
\text { pectoris }\end{array}$ & Syncope & $\begin{array}{c}\text { Conges- } \\
\text { tive } \\
\text { heart } \\
\text { failure }\end{array}$ & $\begin{array}{c}\text { Murmur } \\
\text { of aortic } \\
\text { regurgita- } \\
\text { tion }\end{array}$ & $\begin{array}{l}\text { Electro- } \\
\text { cardio- } \\
\text { gram }\end{array}$ & $\begin{array}{c}\text { Peak } \\
\text { systolic } \\
\text { aorta-LV } \\
\text { gradient } \\
\text { (mm. Hg) }\end{array}$ & $\begin{array}{l}\text { Cal- } \\
\text { cium in } \\
\text { aortic } \\
\text { valve }\end{array}$ & $\begin{array}{l}\text { Weight } \\
\text { of heart } \\
\text { (g.) }\end{array}$ \\
\hline $\begin{array}{l}1 \\
2 \\
3 \\
4\end{array}$ & $\begin{array}{l}28 \mathrm{M} \\
16 \mathrm{M} \\
9 * \mathrm{M} \\
32 \mathrm{M}\end{array}$ & $\begin{array}{l}16 \\
\text { At birth } \\
\text { At birth } \\
5\end{array}$ & $\begin{array}{c}27 \\
9 \\
\text { Asymptomatic } \\
29\end{array}$ & $\begin{array}{l}0 \\
0 \\
0 \\
+\end{array}$ & $\begin{array}{l}0 \\
0 \\
0 \\
0\end{array}$ & $\begin{array}{c}++t+ \\
+ \\
0 \\
+++\end{array}$ & $\begin{array}{l}+ \\
0 \\
0 \\
0\end{array}$ & $\begin{array}{c}\text { Left BBB } \\
\text { LVH, LVS } \\
\text { Normal } \\
\text { Old myo- } \\
\text { cardial } \\
\text { infarct } \\
\text { LVH, LAH }\end{array}$ & $\begin{array}{r}\overline{125} \\
86 \\
90\end{array}$ & $\begin{array}{c}+++t \\
++ \\
0 \\
++t\end{array}$ & $\begin{array}{l}600 \\
650 \\
200 \dagger \\
500\end{array}$ \\
\hline
\end{tabular}

* Died following aortic valvulotomy.

+ Average weight for normal heart in 9-year-old boy is $115 \mathrm{~g}$.

LV, left ventricle; BBB, bundle-branch block; LVH, left ventricular hypertrophy; LVS, left ventricular strain; LAH, left atrial hypertrophy.

\section{Pathological Findings}

The aortic valve in each of the 4 patients consisted of only one cusp and one commissure and was severely stenotic. The appearance of each valve is illustrated in Fig. 1. The single cusp was diffusely fibrotic in all four patients and calcified in three of them. In Case 1 the valve was completely rigid and, since the leaflet could not move during either phase of the cardiac cycle, the valve was regurgitant as well as stenotic. The hearts of all 4 patients demonstrated hypertrophy, predominantly of the left ventricle; in the 3 older patients they weighed 500 to $650 \mathrm{~g}$., and the heart of the child weighed $200 \mathrm{~g}$. (normal $115 \mathrm{~g}$.). The tricuspid, pulmonary, and mitral valves and the coronary arteries were normal in all 4 patients. The heart of Case 4 was placed in a pulse-duplicator (Davila et al., 1956) and the aortic valve was visualized as it functioned (Fig. 2). It was observed that during ventricular diastole the mass of calcium in the valve was pushed against the aortic wall at the sites of the coronary ostia. The relation of the calcified valve to the coronary ostia is also shown in Fig. 3 and 4. This patient had several healed infarcts in the left ventricle and ventricular septum, but the coronary arteries were widely patent and free of atheroma. This combination of findings indicated that infarction had resulted from intermittent occlusion of the coronary ostia by the calcareous mass. Histological examination of the left ventricle of Case 3 revealed extensive areas of acute myocardial necrosis, a finding subsequently proved to result from the use of potassium citrate to induce cardiac arrest (McFarland et al., 1960). 

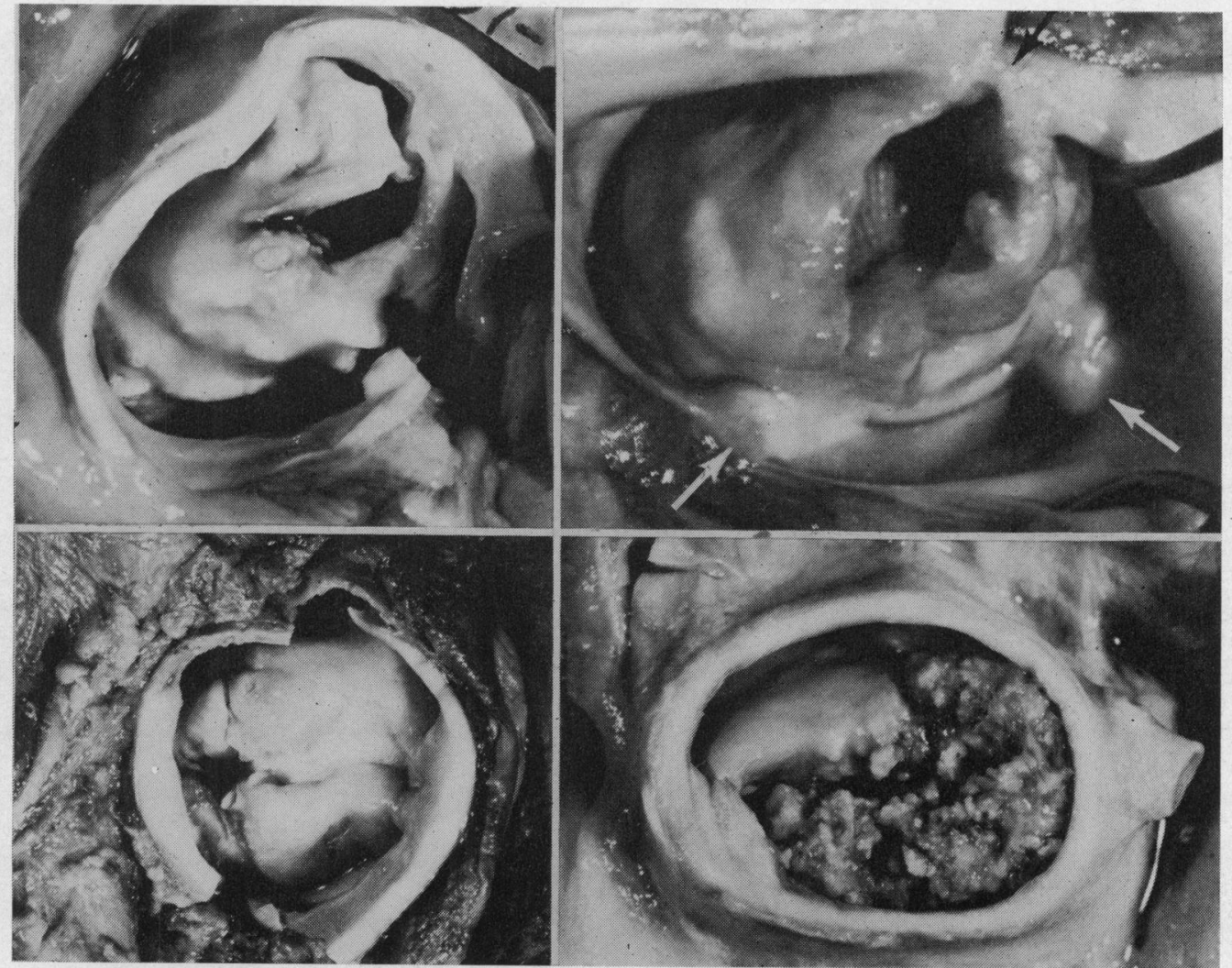

Fig. 1.-Photographs of the aortic valve from above in the four patients. Upper left: Case 1. Upper right: Case 2. Lower left: Case 3. Lower right: Case 4. The arrows in the upper right photograph indicate the true commissure (black arrow) and false commissures or raphes (white arrows).

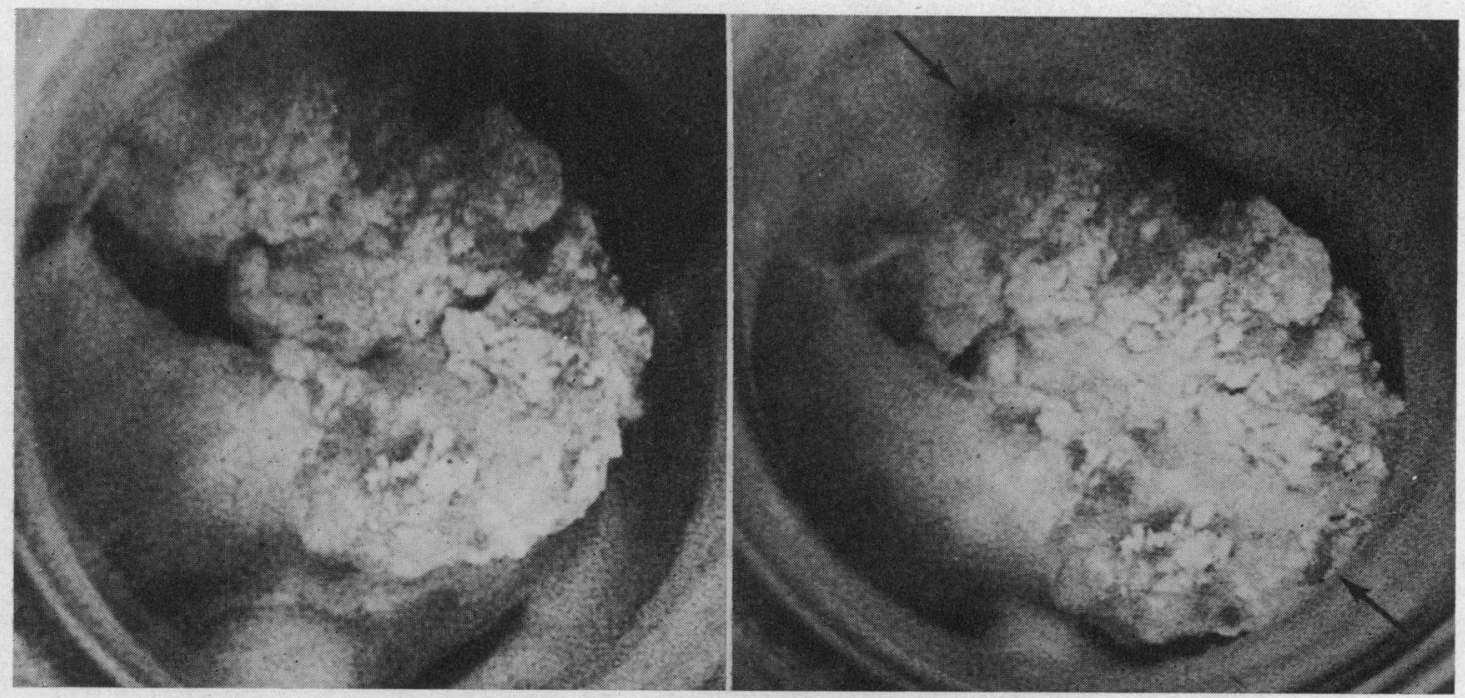

Fig. 2.-Photographs of the aortic valve from above in Case 4, taken from two movie frames with the heart in a pulse duplicator. Left: During ventricular systole: the single commissure is near the $90^{\prime}$ 'clock axis. The valve orifice is eccentrically located and adjacent to the single commissure. Right: During ventricular diastole: during this phase of the cardiac cycle the mass of calcium impinges against the wall of the aorta, opposite the single commissure. The locations of the coronary arterial ostia are indicated by the arrows. In this patient, angina pectoris and myocardial infarction apparently resulted from partial obstruction of the coronary ostia during ventricular diastole by the mass of calcium in the aortic valve. 


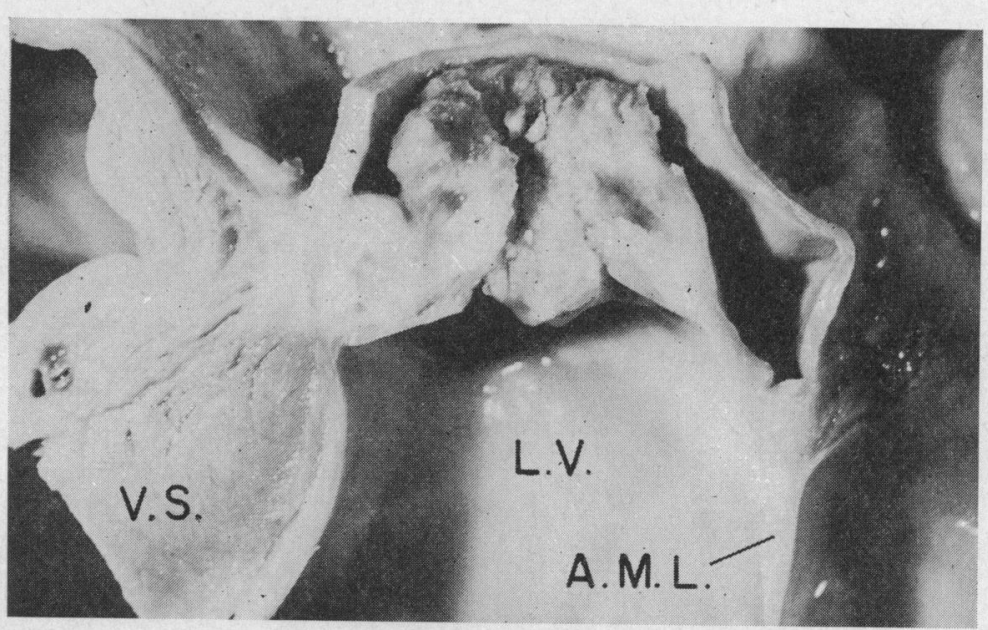

FIG. 3.- Photograph illustrating the aortic valve of Case 4 following removal of its anterior half. The dome-shaped configuration of the valve is apparent. L.V.=left ventricle; V.S.=ventricular septum; A.M.L.=anterior mitral leaflet.

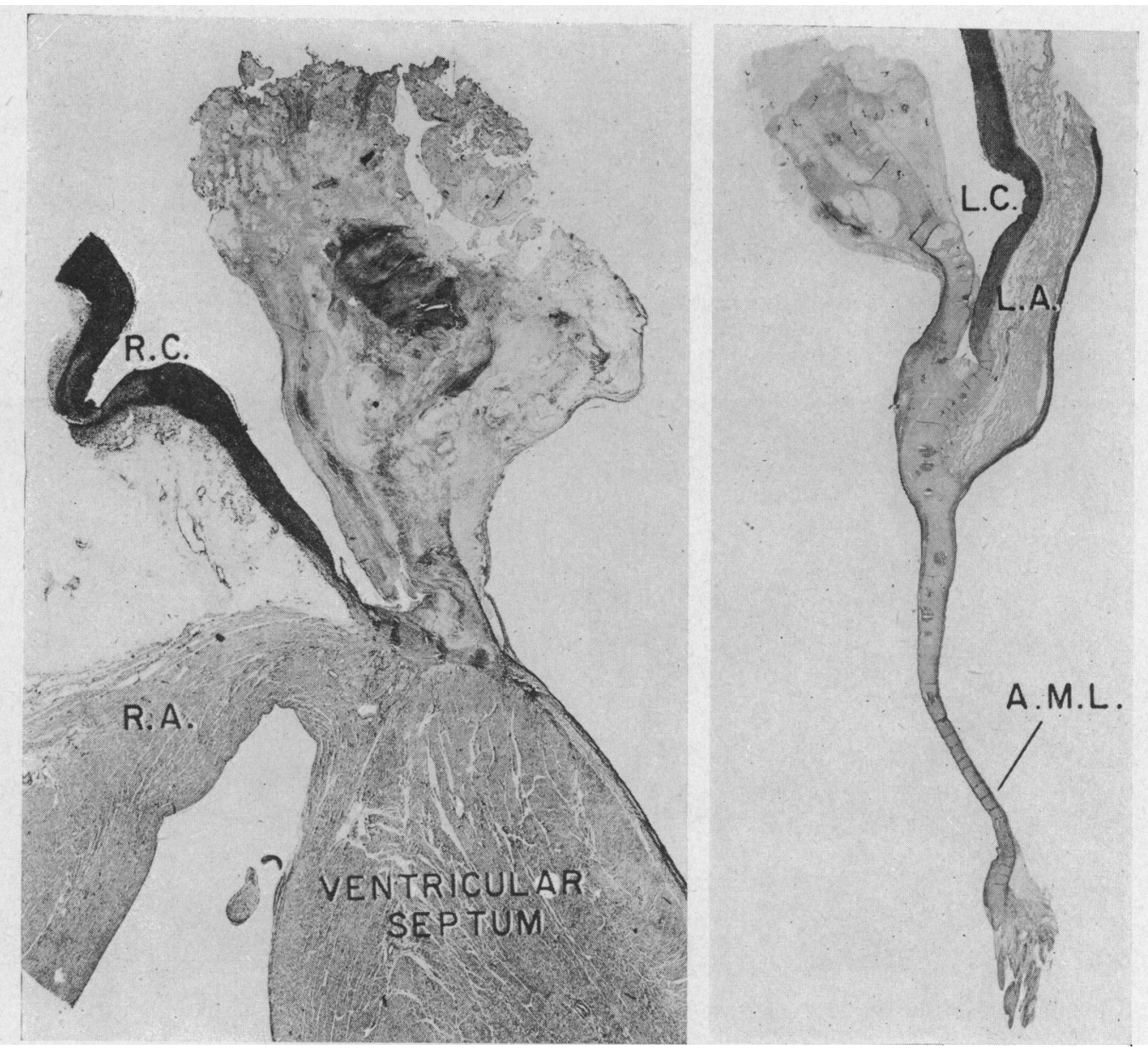

Fig. 4.-Photomicrographs of the fibrotic and calcified aortic valve cusp in Case 4. Left: The ostium of the right coronary artery (R.C.) is shown. Right: The ostium of the left coronary artery (L.C.) is demonstrated. The ostia of both coronary arteries, particularly the left one, were compromised during ventricular diastole by the large calcified mass contacting the aortic wall. R.A.=right atrial wall; L.A.=left atrial wall; A.M.L. =anterior mitral leaflet. (Verhoeff-van Gieson elastic tissue stains; magnification $\times 5$ left, $\times 3$ right.) 
COMMENT

Several anatomically different congenital malformations of the aortic valve producing obstruction to left ventricular outflow have been encountered at open operation. Spencer et al. (1960) found in the majority of their 27 patients that the valve was essentially bicuspid, but a third commissure was often evident. This type of bicuspid valve was present in 29 of the 33 patients described by Ellis and Kirklin (1962), and it also has been the most frequent valvular malformation encountered in this clinic (Morrow, Goldblatt, and Braunwald, 1963). Less commonly, three well-formed leaflets and commissures are present.

Edwards (1958) described the appearance of the aortic valves in three patients studied at necropsy. In each, the valve was dome-shaped, had an eccentrically located orifice (having the appearance of an exclamation point), a single cusp, and a single commissure. He termed this type of valve "unicommissural dome stenosis". Valves of this type, as illustrated by the four patients described above, produce considerable obstruction to left ventricular outflow, but it appears that they cannot be identified pre-operatively by present methods of clinical, hæmodynamic, and angiographic study. Even at operation or necropsy, the unicommissural domed aortic valve may be mistaken for a bicuspid valve, since frequently one or more raphes are present at the base of the aortic wall at some point away from the true commissure. On careful gross examination such raphes may be distinguished from true commissures since they do not extend far from the base of the leaflet toward its free edge; that is, they fail to reach as high on the aortic wall as the true commissure, the height of which equals that of the free margin of the cusp. These raphes, as pointed out by Edwards $(1958,1960)$, do not provide adequate lateral support for the valvular tissue to the aortic wall. Incision of a unicommissural aortic valve, as illustrated in Case 3 (Fig. 5), produces two flaps that have no attachment to the aortic wall, and overwhelming aortic regurgitation is an inevitable sequel.

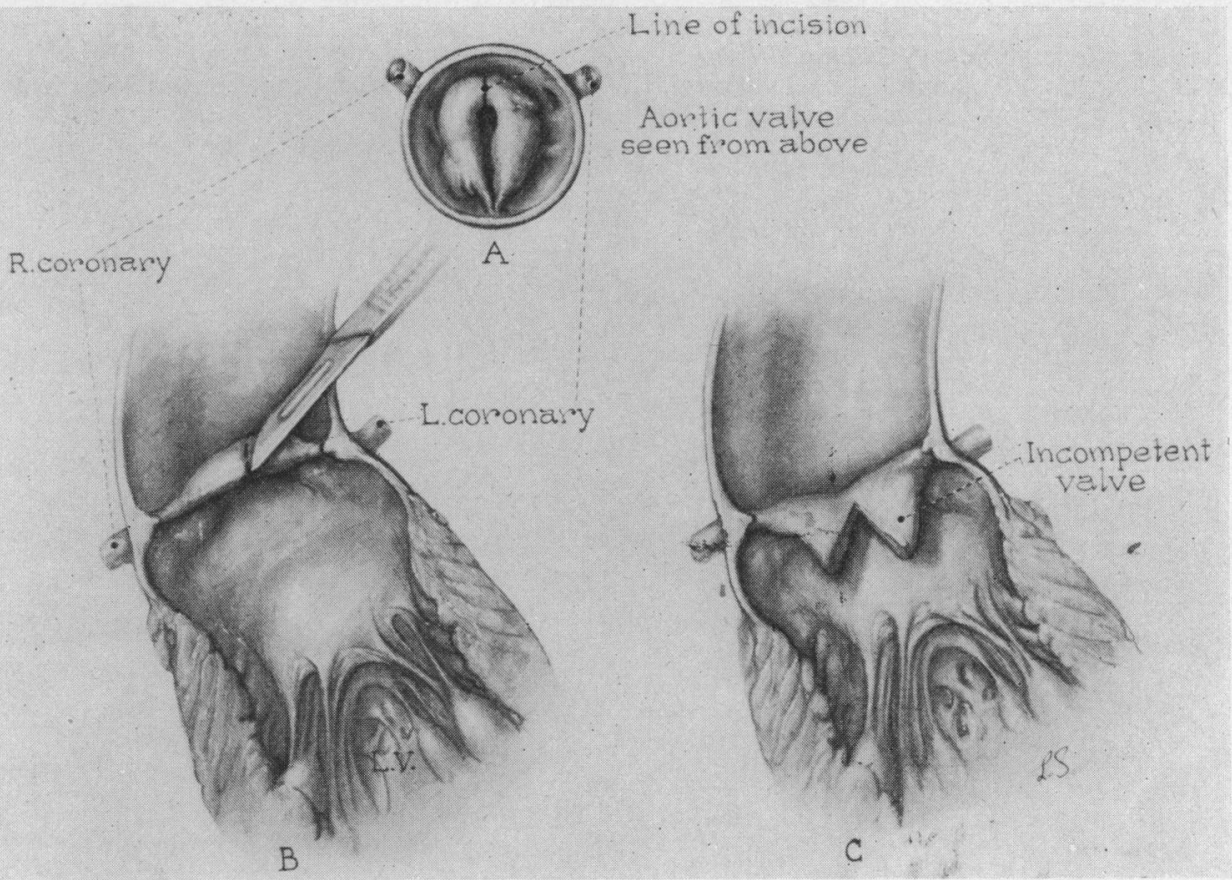

FIG. 5.-Drawings of the aortic valve before and after valvulotomy, Case 3. The true commissure is located at the 6 o'clock axis and two raphes are also present (A). The valve was free of calcium deposits. At operation, the valve was judged to be bicuspid and an incision was made in the cusp opposite the true commissure (B). The incision resulted in two flaps, neither of which had an attachment to the wall of the aorta, and massive aortic regurgitation was produced (C). 
Unicommissural valves were present in two of the patients reported by Ellis and Kirklin (1962), and valvulotomy was performed in each of them. Severe aortic regurgitation did not result, but they do not state whether or not stenosis was relieved. The pathological findings in the present four patients indicate that when left ventricular outflow obstruction is found to be caused by a unicommissural aortic valve, simple valvulotomy is contraindicated and that excision and prosthetic replacement of the valve is the only means by which effective hæmodynamic function can be restored.

\section{SUMMARY}

Four patients are described in whom severe left ventricular outflow obstruction resulted from a congenitally malformed aortic valve which consisted of only a single cusp and a single commissure. The clinical and hæmodynamic examinations did not differ from those seen in patients with the more common types of congenital valvular aortic stenosis. The pathological findings indicate that when this malformation is encountered at operation simple valvulotomy is contraindicated, since massive aortic regurgitation will almost certainly result. The only effective method of surgical treatment appears to be prosthetic replacement of the unicommissural valve.

\section{REFERENCES}

Davila, J. C., Trout, R. G., Sunner, J. E., and Glover, R. P. (1956). A simple mechanical pulse duplicator for cinematography of cardiac valves in action. Ann. Surg., 143, 544.

Edwards, J. E. (1958). Pathologic aspects of cardiac valvular insufficiencies. Arch. Surg., 77, 634.

- (1960). Congenital malformations of the heart and great vessels. Malformations of the valves. In Pathology of the Heart, ed. S. E. Gould, 2nd ed., p. 409. Charles C Thomas, Springfield, Illinois.

Ellis, F. H., and Kirklin, J. W. (1962). Congenital valvular aortic stenosis: Anatomic findings and surgical technique. J. thorac. cardiovasc. Surg., 43, 199.

McFarland, J. A., Thomas, L. B., Gilbert, J. W., and Morrow, A. G. (1960). Myocardial necrosis following elective cardiac arrest induced with potassium citrate. J. thorac. cardiovasc. Surg., 40, 200.

Morrow, A. G., Goldblatt, A., and Braunwald, E. (1963). Congenital aortic stenosis. II. Surgical treatment and the results of operation. Circulation, 27, 450 .

Spencer, F. C., Neill, C. A., Sank, L., and Bahnson, H. T. (1960). Anatomical variations in 46 patients with congenital aortic stenosis. Amer. Surg., 26, 204. 